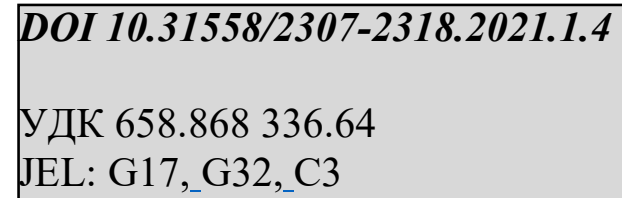

Болгов B.C.

к.е.н., доцент кафедри підприємництва, корпоративної та просторової економіки, Донецький національний університет імені Василя Стуса, м. Вінниця

ORCID: 0000-0002-0631-302X

v.bolgov@donnu.edu.ua

Кушнір I.M.

здобувач, Донецький національний університет імені Василя Стуса, м. Вінниця kushnir.i@,donnu.edu.ua

\title{
МЕХАНІЗМ СТРАТЕГІЧНОГО ФІНАНСОВОГО ПЛАНУВАННЯ НА ПІДПРИЕМСТВІ ПРАТ «ФАРМАЦЕВТИЧНА ФІРМА «ДАРНИЦЯ» МЕТОДОМ КОЕФІЦІЄНТНОГО АНАЛІЗУ
}

У статті проаналізовано роль стратегічного планування як одного з визначальних методів фінансового планування для підприємства в сучасних умовах. Автори дослідили теоретичні особливості стратегічного фінансового планування: його сутність, приничипи $i$ завдання. Окреслили основні принципи проведення стратегічного фінансового планування на вітчизняних підприємств в сучасних умовах. Проаналізували динаміку фінансових результатів діяльності ПрАТ «Фармацевтична фірма «Дарниця». Оиінили фінансовий стан ПрАТ «Фармацевтична фірма «Дарниия», на базі чого розробили стратегічний фінансовий план для изього підприємства на основі методу коефіцієнтного аналізу та економіко-математичної моделі. Проведені дослідження дозволили авторам сформувати пропозиції щзодо поліпшення процесу розробки стратегічного фінансового плану для ПрАТ «Фармачевтична фірма «Дарниия» і підвищення його ефективності.

Ключові слова: фінансове стратегічне планування, показники діяльності, прогноз, ефективність, аналіз.

Табл. - 7, літ. -12

Постановка проблеми. Сьогодні більшість підприємців України недооцінюють важливість стратегічного фінансового планування і не вважають за потрібне до нього звертатися. Це призводить до того, що підприємство виявляється не готовим до непередбачуваних подій (наприклад, COVID-19, економічні кризи, політичні події тощо), немає сформованої «подушки безпеки» та розроблених чітких дій, які б мінімізували вплив на нього. Тому зараз можна спостерігати банкрутство великої кількості підприємстві, які на перший погляд здавалися досить стійкими та витривалими.

Аналіз останніх досліджень та публікацій. Дослідженням стратегічного фінансового планування займалося чимало українських та зарубіжних діячів науки. Наприклад, 3 українських науковців можна виділити таких вчених, як О. Біла, Н. Гринюк, Н. Гуляєва, Н. Давиденко, Я. Дропа, Є. Іонін, О. Кравченко, О. Марченко, В. Марцин, К. Редченко, Г. Ситник, А. Семенов, Г. Тарасюк, С. Тесля, Л. Швайка, а з закордонних Р. Акофф, Ю. Брігхем, Р. Вестерфілд, С. Маєрс, П. Петерсон, Д. Хорн тощо. 
Метою дослідження $\epsilon$ визначення сутності стратегічного фінансового планування та застосування на практиці одного з методів даного виду планування.

Викладення основного матеріалу. Важливою складовою успішного ведення підприємницької діяльності та ефективного використання фінансових ресурсів підприємства $\epsilon$ фінансове планування. Адже вже $є$ доведеним на практиці країн з ринковою економікою, що чим більш досконалим $\epsilon$ фінансове планування, тим більш ефективним $\epsilon$ діяльність підприємства, а також управління нею.

Фінансове планування - це процес розробки системи фінансових планів, який полягає у визначенні фінансових цілей, встановленні ступеня відповідності цих цілей поточному фінансовому стану підприємства та формулюванні послідовності дій, спрямованих на досягнення поставлених цілей [1]. Фінансове планування дає змогу проводити постійний фінансовий контроль за створенням та раціональним використанням фінансових ресурсів у майбутньому. Воно дозволяє дослідити та порівняти різні варіанти фінансової стратегії підприємства, а також забезпечити сталі ринкові позиції та покращити фінансове становище. Теоретики виділяють 3 види фінансово планування:

1) Операційне планування (розробляється на місяць, квартал чи декаду);

2) Поточне планування (розробляється на термін - 1 рік);

3) Стратегічне планування (розробляється на 3-5 років, а деякі великі національні та транснаціональні компанії можуть складати фінансовий план і на 10-15 років).

Стратегічне фінансове планування - це процес розробки системи фінансових планів $\mathrm{i}$ планових (нормативних) показників із забезпечення розвитку підприємства необхідними фінансовими ресурсами та підвищення ефективності його звичайної діяльності у майбутньому періоді [2].

Метою стратегічного фінансового планування на підприємстві є забезпечити майбутню операційну та інвестиційну діяльність необхідними фінансовим ресурсами для здійснення ефективної господарської діяльності та досягнення прибутковості підприємства.

Результатом $\epsilon$ розробка трьох основних фінансових документів: прогноз звіту про прибутки і збитки; прогноз руху грошових коштів; прогноз бухгалтерського балансу [3].

Стратегічне фінансове планування грунтується на моделюванні та прогнозуванні, яке в свою чергу основане на методах економетричного моделювання, лінійного або нелінійного програмування.

Методи планування - це конкретні засоби та прийоми розрахунку планових показників [3]. Найбільш поширеними методами стратегічного (фінансового) планування є:

- Балансовий метод

- Розрахунково-аналітичний метод

- Нормативний метод

- Метод економіко-математичного модулювання

- Коефіцієнтний, або метод відсотка від реалізації

- Метод прогнозування

- Метод оптимізації планових рішень тощо.

Кожний із вище перерахованих методів включає в себе десятки різновидів, що використовуються в залежності від сфери діяльності підприємства, зовнішнього середовища підприємства, країни, в якій знаходиться підприємства, та їі законодавства та інших факторів.

Під час вибору оптимального методу стратегічного фінансового планування управлінець повинен керуватися такими принципами:

1) Відповідати зовнішньому середовищу підприємства, особливостям ринку, попиту, конкуренції тощо; 
2) Максимально враховувати характерні риси господарської діяльності підприємства;

3) Враховувати залежність вибору методу від вибраного типу планування тощо.

Проаналізувавши всі вище вказані методи, принципи їхнього вибору та фінансову звітність ПрАТ «Фармацевтична фірма «Дарниця», було визначено, що найефективнішим методом стратегічного фінансового планування обраного підприємства буде метод коефіцієнтного аналізу.

Враховуючи епідеміологічну ситуацію в Україні та прогнози фахівців фармацевтичної галузі, можна припустити зростання обсягів виробництва та реалізації продукції Компанії у 2020 р. на $35 \%$, у 2021 р. на 28\% (прогнозується зниження захворюваності на Covid-19), а далі на 19,7\% (середнє зростання обсягів реалізації з 2010-2019 рр.). Відповідно, дане припущення буде базою для розробки стратегічного фінансового плану.

Коефіцієнтний аналіз буде проводитися в кілька етапів. На першому етапі слід проаналізувати основні показники господарської діяльності за певний проміжок часу. Аналіз передбачає визначення частки витрат у продажах за останні кілька років (табл. 1). Найбільш реалістичного прогнозу можна досягти, якщо аналізувати показники за 5 років.

Таблиця 1 - Аналіз основних показників діяльності ПрАТ «Фармацевтична фірма «Дарниця» за 2015-2019 pp.

\begin{tabular}{|l|c|c|c|c|c|c|}
\hline \multicolumn{1}{|c|}{ Показник } & 2015 & 2016 & 2017 & 2018 & 2019 & $\begin{array}{c}\text { Середне } \\
\text { значення }\end{array}$ \\
\hline Відношення собівартості до чистого доходу & 0,398 & 0,458 & 0,463 & 0,470 & 0,416 & 0,441 \\
\hline Відношення грошових коштів до виручки & 0,033 & 0,001 & 0,042 & 0,071 & 0,078 & 0,045 \\
\hline Відношення запасів до виручки & 0,313 & 0,277 & 0,213 & 0,177 & 0,175 & 0,231 \\
\hline Відношення необоротних активів & 0,489 & 0,431 & 0,372 & 0,675 & 0,321 & 0,458 \\
\hline Відношення оборотних активів & 0,823 & 0,852 & 0,846 & 0,685 & 0,721 & 0,785 \\
\hline Відношення вартості основних засобів до виручки & 0,348 & 0,264 & 0,223 & 0,203 & 0,190 & 0,246 \\
\hline $\begin{array}{l}\text { Відношення поточна кредиторської } \\
\text { заборгованості до виручки }\end{array}$ & 0,319 & 0,296 & 0,131 & 0,089 & 0,087 & 0,184 \\
\hline $\begin{array}{l}\text { Відношення дебіторської заборгованості до } \\
\text { виручка }\end{array}$ & 0,610 & 0,501 & 0,510 & 0,703 & 0,994 & 0,664 \\
\hline Відношення власного капіталу до виручки & 0,989 & 0,984 & 0,964 & 0,978 & 0,531 & 0,889 \\
\hline
\end{tabular}

Отже, на основі результатів розрахованих в таблиці 1, в подальшому формується прогноз фінансових результатів та балансу підприємства. У 2015 році відношення собівартості до виручки складало 39,8\% (на 1 грн виручки підприємство витратила 39,8 коп.), а в 2019 р. вже 41,6\%, або ж для отримання 1 грн виручки було затрачено вже 41,6 копійки. За 2015-2019 р. зросло також відношення дебіторської заборгованості до виручки (на 38,4\%). Решта показників зазнали зменшення.

Другим етапом коефіцієнтного аналізу є складання прогнозу про фінансові результати підприємства (табл. 3). Даний етап здійснюється для прогнозування прибутку. Під час розрахунку майбутнього чистого прибутку бралося за основу те, що господарські витрати повинні зростати пропорційно до росту обсягу реалізованої продукції, а собівартість реалізованої продукції має визначатися як добуток прогнозованого чистого доходу за поточний рік та середнього значення показника відношення витрат до виручку (табл. 2).

Відповідно до отриманих даних в Таблиця 2, якщо припустити, що в 2020 році обсяг реалізації збільшиться на 30\%, то і інші витрати підприємства мають збільшитись також на 30 \%. Тоді чистий дохід від реалізації продукції буде становити 4305733,9 тис. грн, в результаті обрахунку чистий прибуток становитиме 578974 тис. грн, що на 5\% менше, ніж у 2019 році. Проте в наступні роки ситуація значно покращується і в 2024 році прогноз 
чистого прибутку становить 1271017,4 тис. грн, тобто приблизно в двічі більше, ніж Компанія отримала у 2019 р.

Таблиця 2 - Прогноз даних звіту про фінансові результати ПрАТ «Фармацевтична фірма «Дарниця» на 2020 р., тис. грн.

\begin{tabular}{|c|c|c|c|}
\hline Показник & $\begin{array}{l}\text { Дані за } \\
2019 \text { р. }\end{array}$ & Формула розрахунку & $\begin{array}{l}\text { Прогноз на } \\
2020 \text { р. }\end{array}$ \\
\hline $\begin{array}{l}\text { Чистий дохід (виручка) від } \\
\text { реалізації продукції (товарів, } \\
\text { робіт, послуг) }\end{array}$ & 3312103 & 1,3 · продажі за 2019 p. & 4305733,9 \\
\hline $\begin{array}{l}\text { Собівартість реалізованої } \\
\text { продукції (товарів, робіт, } \\
\text { послуг) }\end{array}$ & 1376318 & 0,441 · продажі за 2020 p. & 1898828,65 \\
\hline Валовий прибуток & 1935785 & $\begin{array}{c}\text { Виручка за } 2020 \text { p. - Собівартість за } \\
2020 \text { р. }\end{array}$ & 2406905,25 \\
\hline Інші операційні доходи & 18882 & 1,3 · інші операційні доходи за 2019 р. & 24546,6 \\
\hline Адміністративні витрати & $(215595)$ & 1,3 · адміністративні витрати за 2019 р. & $(280273,5)$ \\
\hline Витрати на збут & $(694444)$ & $1,3 \cdot$ витрати на збут за 2019 р. & $(902777,2)$ \\
\hline Інші операційні витрати & $(213083)$ & $1,3 \cdot$ інші операційні витрати за 2019 p. & 277007,9 \\
\hline $\begin{array}{l}\text { Фінансовий результат від } \\
\text { операційної діяльності } \\
\text { (прибуток) }\end{array}$ & 831545 & $\begin{array}{c}\text { Валовий прибуток за } 2020 \text { р. + інші } \\
\text { операційні доходи за } 2020 \text { р. - } \\
\text { адміністративні витрати за } 2020 \text { р. - } \\
\text { витрати на збут за } 2020 \text { р. - - інші } \\
\text { операційні витрати за } 2020 \text { р. }\end{array}$ & 971393,25 \\
\hline Інші фінансові доходи & 27858 & 1,3 · інші фінансові доходи за 2019 р. & 36215,4 \\
\hline Інші доходи & 10460 & 1,3 · Інші доходи за 2019 р. & 13598 \\
\hline Фінансові витрати & $(242409)$ & 1,3 · фінансові витрати за 2019 р. & $(315131,7)$ \\
\hline Інші витрати & (7) & 1,3 · інші витрати за 2019 р. & $(9,1)$ \\
\hline $\begin{array}{l}\text { Фінансовий результат до } \\
\text { оподаткування (прибуток) }\end{array}$ & 719888 & $\begin{array}{c}\text { Фінансовий результат від операційної } \\
\text { діяльності (прибуток) за } 2020 \text { р. + інші } \\
\text { фінансові доходи за } 2020 \text { р. + інші } \\
\text { доходи за } 2020 \text { р. - фінансові витрати за } \\
2020 \text { р. - інші витрати за } 2020 \text { р. }\end{array}$ & 706065,85 \\
\hline $\begin{array}{l}\text { Витрати з податку на прибуток } \\
(18 \%)\end{array}$ & $(110259)$ & $\begin{array}{c}\text { Фінансовий результат до оподаткування } \\
\text { (прибуток) за } 2020 \text { р. } \cdot 18 \%\end{array}$ & $(127091,85)$ \\
\hline $\begin{array}{l}\text { Чистий фінансовий результат } \\
\text { (прибуток) }\end{array}$ & 609629 & $\begin{array}{c}\text { Фінансовий результат до оподаткування } \\
\text { (прибуток) за } 2020 \text { р. - витрати } 3 \\
\text { податку на прибуток за } 2020 \text { р. (18\%) }\end{array}$ & 578974 \\
\hline
\end{tabular}

Отже, можна стверджувати, що підприємства і надалі буде розширювати виробництво та збільшувати обсяг реалізації продукції. За прогнозований період планується збільшення чистого доходу та чистого прибутку більш ніж у 2 рази.

Таблиця 3 - Прогноз даних звіту про фінансові результати ПрАТ «Фармацевтична фірма «Дарниця» на 2020-2024 рр., тис. грн.

\begin{tabular}{|l|c|c|c|c|c|}
\hline \multicolumn{1}{|c|}{ Показники } & $\begin{array}{c}2020 \mathrm{p} . \\
(+30 \%)\end{array}$ & $\begin{array}{c}2021 \mathrm{p} . \\
(+28 \%)\end{array}$ & $\begin{array}{c}2022 \mathrm{p} . \\
(+19,7 \%)\end{array}$ & $\begin{array}{c}2023 \mathrm{p} . \\
(+19,7 \%)\end{array}$ & $\begin{array}{c}2024 \mathrm{p} . \\
(+19,7 \%)\end{array}$ \\
\hline \multicolumn{1}{|c|}{} & 2 & 3 & 4 & 5 & 6 \\
\hline $\begin{array}{l}\text { Чистий дохід (виручка) від } \\
\text { реалізації продукції }\end{array}$ & 4305733,9 & 5511339,4 & 6597073,3 & 7896696,7 & 9452345,9 \\
\hline $\begin{array}{l}\text { Собівартість реалізованої } \\
\text { продукції }\end{array}$ & 1898828,7 & 2430500,7 & 2909309,3 & 3482443,2 & 4168484,6 \\
\hline Валовий прибуток & 2406905,3 & 3080838,7 & 3687763,9 & 4414253,4 & 5283861,4 \\
\hline Інші операційні доходи & 24546,6 & 31419,6 & 37609,3 & 45018,4 & 53887,0 \\
\hline
\end{tabular}


Продовження табл.3

\begin{tabular}{|c|c|c|c|c|c|}
\hline 1 & 2 & 3 & 4 & 5 & 6 \\
\hline Адміністративні витрати & $(280273,5)$ & $(358750,1)$ & $(429423,8)$ & $(514020,3)$ & $(615282,4)$ \\
\hline Витрати на збут & $(902777,2)$ & $(1155554,8)$ & $(1383199,1)$ & $(1655689,3)$ & $(1981860,1)$ \\
\hline Інші операційні витрати & $(277007,9)$ & $(354570,1)$ & $(424420,4)$ & $(508031,2)$ & $(608113,4)$ \\
\hline $\begin{array}{lr}\text { Фінансовий } & \text { результат від } \\
\text { операційної } \\
\text { (прибуток) }\end{array}$ & 971393,3 & 1243383,4 & 1488329,9 & 1781530,9 & 2132492,5 \\
\hline Інші фінансові доходи & 36215,4 & 46355,7 & 55487,8 & 66418,9 & 79503,4 \\
\hline Інші доходи & 13598,0 & 17405,4 & 20834,3 & 24938,7 & 29851,6 \\
\hline Фінансові витрати & $(315131,7)$ & $(403368,6)$ & $(482832,2)$ & $(577950,1)$ & $(691806,3)$ \\
\hline Інші витрати & $(9,1)$ & $(11,6)$ & $(13,9)$ & $(16,7)$ & $(20,0)$ \\
\hline $\begin{array}{l}\text { Фінансовий результат до } \\
\text { оподаткування (прибуток) }\end{array}$ & 706065,9 & 903764,3 & 1081805,9 & 1294921,6 & 1550021,2 \\
\hline 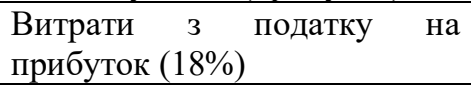 & $(127091,9)$ & $(162677,6)$ & $(194725,1)$ & $(233085,9)$ & $(279003,8)$ \\
\hline $\begin{array}{l}\text { Чистий фінансовий результат } \\
\text { (прибуток) }\end{array}$ & 578974,0 & 741086,7 & 887080,8 & 1061835,7 & 1271017,4 \\
\hline
\end{tabular}

На третьому етапі розробляється прогноз щодо статей балансу підприємства (табл. 5). Даний метод стратегічного (фінансового) прогнозування передбачає, що зростання активів та пасиві за прогнозований період також буде відбуватися. Тому прогнозовані показники визначаються із врахуванням відношення статей балансу до виручки, а також прогнозованого чистого доходу (табл. 4).

Таблиця 4 - Прогноз балансу ПрАТ «Фармацевтична фірма «Дарниця» на 2020 р., тис. грн

\begin{tabular}{|c|c|c|c|}
\hline Показник & 2019 p. & Формула & $2020 \mathrm{p}$. \\
\hline \multicolumn{4}{|c|}{ Активи } \\
\hline Необоротні активи & 1063735 & $0,458 \cdot$ продажі за 2020 p. & 1972026,13 \\
\hline - в т.ч.: основні засоби & 630408 & 0,246 · продажі за 2020 p. & 1059210,54 \\
\hline Оборотні активи & 2387431 & $0,785 \cdot$ продажі за 2020 p. & 3380001,11 \\
\hline - в т.ч. : запаси & 581168 & $0,231 \cdot$ продажі за 2020 p. & 994624,53 \\
\hline $\begin{array}{l}\text { - дебіторська заборгованість за продукцію, } \\
\text { товари, роботи, послуги }\end{array}$ & 1368506 & 0,664 · продажі за 2020 p. & 2859007,31 \\
\hline - гроші та їх еквіваленти & 257797 & $0,045 \cdot$ продажі за 2020 p. & 193758,03 \\
\hline Баланс & 3451166 & & 10458627,65 \\
\hline \multicolumn{4}{|c|}{ Пасив } \\
\hline Власний капітал & 1759996 & $0,889 \cdot$ продажі за 2020 p. & 3827797,44 \\
\hline Довгострокові зобов'язання і забезпечення & 1404489 & $+4434086,17$ & 5838575,17 \\
\hline Поточні зобов’язання і забезпечення & 546089 & $0,184 \cdot$ продажі за 2020 p. & 792255,04 \\
\hline Баланс & 3451166 & & 10458627,65 \\
\hline Необхідні додаткові фонди & & $+4434086,17$ & \\
\hline
\end{tabular}

Отже, за рахунок зростання продажів відбудеться зростання і пасивів, і активів. Аналіз показав, що у 2020p. в порівняння з 2024 р. буде спостерігатися значне зростання балансу (приблизно у 3 рази), за рахунок цього підприємству потрібно буде збільшити свої довгострокові зобов'язання і забезпечення на 4434086,17 тис. грн. Аналіз прогнозованого балансу підприємства показав, що активи та пасиви зростають пропорційно до обсягів продажів. У 2020 р. кількість необоротних активів становила 1972026,1 тис. грн, а в 2024 р. вже 4329174,4 тис. грн (зросло на 120\%). Така ж ситуація спостерігається і з пасивами. Також розрахунок показав, що якщо прогнози справдяться, то у 2021 р. уде спостерігатися надлишок пасивів у розмірі 4901647,5 тис. грн, а в інші роки недостача. 
Таблиця 5 - Прогноз балансу ПрАТ «Фармацевтична фірма «Дарниця» на 2020 р., тис. грн

\begin{tabular}{|c|c|c|c|c|c|}
\hline Показник & $2020 \mathrm{p}$. & $2021 \mathrm{p}$ & $2022 \mathrm{p}$. & $2023 \mathrm{p}$. & $2024 \mathrm{p}$. \\
\hline \multicolumn{6}{|c|}{ Активи } \\
\hline Необоротні активи & 1972026,1 & 2524193,4 & 3021459,5 & 3616687,1 & 4329174,4 \\
\hline - в т.ч.: основні засоби & 1059210,5 & 1355789,5 & 1622880,0 & 1942587,4 & 2325277,1 \\
\hline Оборотні активи & 3380001,1 & 4326401,4 & 5178702,5 & 6198906,9 & 7420091,6 \\
\hline - в т.ч. : запаси & 994624,5 & 1273119,4 & 1523923,9 & 1824136,9 & 2183491,9 \\
\hline $\begin{array}{l}\text { - дебіторська заборгованість за } \\
\text { продукцію, товари, роботи, } \\
\text { послуги }\end{array}$ & 2859007,3 & 3659529,4 & 4380456,6 & 5243406,6 & 6276357,7 \\
\hline - гроші та їх еквіваленти & 193758,0 & 2480 & 296868,3 & 355351,4 & 425355,6 \\
\hline Баланс & 10458627,7 & 6850594,9 & 8200162,1 & 9815594,0 & 11749266,0 \\
\hline \multicolumn{6}{|c|}{ асив } \\
\hline Власний капітал & 3827797,4 & 4899580,7 & 5864798,1 & 7020163,4 & 8403135,5 \\
\hline $\begin{array}{l}\text { Довгострокові зобов'язання і } \\
\text { забезпечення }\end{array}$ & 5838575,2 & 936927,7 & 1121502,5 & 1342438,4 & 1606898,8 \\
\hline $\begin{array}{ll}\text { Поточні } & \text { зобов’язання } \\
\text { забезпечення }\end{array}$ & 792255,0 & 1014086,4 & 1213861,5 & 1452992,2 & 1739231,7 \\
\hline Баланс & 10458627,7 & 6850594,9 & 8200162,1 & 9815594,0 & 11749266,0 \\
\hline Необхідні додаткові фонди & $+4434086,2$ & $-4901647,5$ & $+184574,8$ & $+220936,0$ & $+264460,4$ \\
\hline
\end{tabular}

Заключним етапом кореляційного аналізу $\epsilon$ прогнозування деяких показників фінансового стану підприємства. Прогноз буде здійснюватися таких показників: коефіцієнт рентабельності активів; коефіцієнт рентабельності продаж; коефіцієнт рентабельності власного капіталу; коефіцієнт поточної ліквідності (покриття); коефіцієнт автономії (фінансової незалежності); коефіцієнт фінансової залежності; коефіцієнт мобільності активів; коефіцієнт самофінансування.

Вище вказані коефіцієнти розраховуються на основі формул описаних в таблиці 6.

Таблиця 6 - Ключові показники коефіцієнтного аналізу

\begin{tabular}{|c|c|c|c|}
\hline Показник & Формула & Умовні позначення & $\begin{array}{c}\text { Нормативне } \\
\text { значення }\end{array}$ \\
\hline $\begin{array}{l}\text { Коефіцієнт рентабельності } \\
\text { активів }\end{array}$ & $\frac{\Pi}{\left(A_{\Pi}+A_{\kappa}\right) / 2}$ & $\begin{array}{l}\text { П - Чистий прибуток (збиток); } \\
\mathrm{A}_{\Pi}-\text { активи на початок періоду; } \\
\mathrm{A}_{\kappa}-\text { активи на кінець періоду }\end{array}$ & \multirow{3}{*}{ Зростання } \\
\hline $\begin{array}{l}\text { Коефіцієнт рентабельності } \\
\text { продаж }\end{array}$ & $\frac{\Pi}{\text { ЧД }}$ & $\begin{array}{l}\text { П - Чистий прибуток; } \\
\text { ЧД - Чистий доход (виручка) від } \\
\text { реалізації продукції }\end{array}$ & \\
\hline $\begin{array}{l}\text { Коефіцієнт рентабельності } \\
\text { власного капіталу }\end{array}$ & $\frac{\Pi}{\left(B K_{\Pi}+B K_{K}\right) / 2}$ & $\begin{array}{l}\text { П - прибуток; } \\
\text { ВК - Власний капітал на початок } \\
\text { періоду; } \\
\text { ВК } \text { - Власний капітал на кінець } \\
\text { періоду }\end{array}$ & \\
\hline $\begin{array}{l}\text { Коефіцієнт } \\
\text { ліквідності (покриття) }\end{array}$ & $\frac{\mathrm{OA}}{\Pi 3}$ & $\begin{array}{l}\text { ОА - оборотні активи; } \\
\text { ПЗ - поточні зобов'язання }\end{array}$ & $1-3$ \\
\hline $\begin{array}{l}\text { Коефіцієнт фінансової } \\
\text { незалежності (автономії) }\end{array}$ & $\frac{\mathrm{BK}}{\Pi}$ & \multirow{2}{*}{$\begin{array}{l}\text { ВК - Власний капітал; } \\
\text { П - Пасиви }\end{array}$} & $0,4-0,6$ \\
\hline $\begin{array}{ll}\text { Коефіцієнт } & \text { фінансової } \\
\text { залежності } & \\
\end{array}$ & $\frac{\Pi}{\mathrm{BK}}$ & & Зростання \\
\hline $\begin{array}{l}\text { Коефіцієнт } \quad \text { мобільності } \\
\text { активів }\end{array}$ & $\frac{\mathrm{OA}}{\mathrm{HA}}$ & $\begin{array}{l}\text { ОА - Оборотні активи; } \\
\text { НА - Необоротні активи }\end{array}$ & $\begin{array}{l}\text { Немає (для } \\
\text { кожної галузі } \\
\text { різний) }\end{array}$ \\
\hline Коефіцієнт фінансування & $\frac{\mathrm{BК}}{(Д 3+К З)}$ & $\begin{array}{l}\text { ВК - Власний капітал; } \\
\text { Д3 - Довгострокові зобов’язання } \\
\text { К3 - Короткострокові зобов’язання }\end{array}$ & $\geq 1$ \\
\hline
\end{tabular}


На основі формул коефіцієнтів фінансового стану описаних в таблиці 6 розраховано прогнозовані показники фінансового стану на термін з 2020 р. до 2024 р. (табл. 7).

Таблиця 7 - Аналіз показників прогнозу балансу і звіту про фінансові результати ПрАТ «Фармацевтична фірма «Дарниця» за 2020-2024 pp.

\begin{tabular}{|l|c|c|c|c|c|}
\hline \multicolumn{1}{|c|}{ Показники } & 2020 & 2021 & 2022 & 2023 & 2024 \\
\hline Коефіціснт рентабельності активів & 0,055 & 0,108 & 0,108 & 0,108 & 0,108 \\
\hline Коефіціснт рентабельності продажів & 0,134 & 0,134 & 0,134 & 0,134 & 0,134 \\
\hline Коефіціснт рентабельності власного капіталу & 0,151 & 0,151 & 0,151 & 0,151 & 0,151 \\
\hline Коефіціснт поточної ліквідності (покриття) & 4,266 & 4,266 & 4,266 & 4,266 & 4,266 \\
\hline Коефіцієнт фінансової незалежності (автономії) & 0,366 & 0,715 & 0,715 & 0,715 & 0,715 \\
\hline Коефіціснт фінансової залежності & 2,732 & 1,398 & 1,398 & 1,398 & 1,398 \\
\hline Коефіціснт мобільності активів & 1,714 & 1,714 & 1,714 & 1,714 & 1,714 \\
\hline Коефіціснт самофінансування & 1,941 & 1,941 & 1,941 & 1,941 & 1,941 \\
\hline
\end{tabular}

Прогноз фінансового стану на 2020-2024 рр. показав, що ПрАТ «Фармацевтична фірма «Дарниця» у фінансовому плані буде досить стійким, адже коефіцієнт покриття значно перевищує нормативне значення і становить 4,266. Прогнозована рентабельність активів знизиться у 2020 р. в порівнянні із 2019 р. на 0,122, але вже в 2021 р. покращиться і становитиме 0,108 . Рентабельність продажів становитиме $13,4 \%$, а власного капіталу $15,1 \%$ (тобто зменшиться в порівнянні із 2019 р. на 5,5\%). У 2020 р. буде спостерігатися погіршення показників автономії (зменшиться на 1,444) та фінансової незалежності (збільшиться на 0,771), але ситуація кардинально змінюється в позитивний бік. Коефіцієнти мобільності і самофінансування протягом 2020-2024 pр. знаходяться на одному рівні, дані показники значно перевищують норматив. Узагальнюючи аналіз отриманих даних можна сказати, що у 2020 р. фінансовий стан підприємства значно погіршиться, проте все нормалізується в 2021 р.

Детально дослідивши стратегічне фінансове планування та проаналізувавши отримані дані під час планування фінансової діяльності ПрАТ «Фармацевтична фірма «Дарниця», можна сформувати наступні пропозиції щодо покращення процесу стратегічного фінансового планування:

1) Провести комплексний та детальний аналіз сильних та слабких сторін, загроз та можливостей (SWOT), а також проаналізувати фінансові показники, продукцію підприємства та визначити який товар $\epsilon$, так званою «Зіркою» та «Дійною коровою», чи «Важкими дітьми» та « Собаками» (матриця BKG);

2) У процесі розробки плану обов'язковою складовою має виступати зовнішнє середовище, адже воно безпосередньо впливає на роботу підприємства i його прибутковість, визначає попит та пропозицію на фармацевтичному ринку;

3) Дослідити ефективність стратегічного фінансового плану підприємства в минулому, визначити ступінь наближення цього плану до реальних показників, проаналізувати допущені помилки та, за наявності, причини віддаленості реальних показників від прогнозованих;

4) Під час формування стратегічного плану прибігти до досвіду інших компаній фармацевтичної галузі не лише в Україні, а й за кордоном. Дослідити зразки успішних та провальних стратегічних фінансових планів, щоб мінімізувати неточності та помилки під час складання власних планів;

5) План має базуватися та розроблятися для досягнення реалістичних цілей та на основі чітко розставлених пріоритетів. Це дозволить розмежувати місію та стратегії (як 
загальні так і фінансові) підприємства, в наслідок чого даний план буде більш ефективніше реалізовано;

6) Стратегічне фінансове планування має бути варіативне, тобто повинні бути наявні альтернативні припущення («оптимальний», «песимістичний» та «реалістичний» варіант). Це дасть змогу компанії більш ефективно підготуватися до різних сценаріїв розвитку та зменшити вплив ризиків;

7) Сформувати та дотримуватися чіткої послідовності розробки фінансового плану. Порядок дій повинен формуватися окремо для кожного підприємства, в залежності від виду діяльності, рівня складності господарських процесів, ринку на якому він діє тощо;

8) Опиратися на достовірну та повну інформаційно-аналітичну базу, що дає змогу підвищити реалістичність складеного плану. Ця база формується на основі:

а) покращення форми первинної інформації та методи її отримання;

б) покращення обробки інформації та шляхів якими вона отримується;

в) покращення процесу обліку та упорядкування отриманої інформації.

Стратегічний фінансовий план ПрАТ «Фармацевтична фірма «Дарниця» повинен розроблятися на 3-5 років, та розділятися на 12-ти місячні відрізки. Проте сучасні умови нестабільності, пов'язаної із політикою держав, епідеміологічного ситуацією, економічному кризами та інше, роблять такий план неефективним та провальним. Підприємство для ефективної реалізацій стратегічного фінансового плану повинно регулярно (раз на 1-2 роки) переглядати його та оновлювати, відповідно до змін.

Висновки. Стратегічне фінансове планування являє собою одне із важливих факторів рентабельної діяльності підприємства, адже на їхній основі розробляються ключові управлінські рішенні, розробляються стратегічні цілі та завдання, окреслюються чіткі орієнтири розвитку підприємства. В результаті проведеного аналізу було визначено, що за наявних чинників найбільш доцільним буде розробити стратегічний фінансовий план методом коефіцієнтного аналізу. Основою коефіцієнтного методу є припущення щодо обсягів майбутніх продажів. Враховуючи сучасні реалії, можна припустити, що у 2020 р. збільшення обсягу реалізації фармацевтичної продукції на 30\%, у 2021 р. - на 28\%, а у 2022-2024 - на 19,7\%. Тому виходячи з цього цілком реально, що чистий прибуток у 2020 2024 р. буде зростати, а підприємство і надалі процвітати.

\section{СПИСОК ВИКОРИСТАНИХ ДЖЕРЕЛ}

1. Шелудько В.М. Фінансовий менеджмент: навч. посіб. Київ: Наукова думка, 2013. 375 с.

2. Білик М.Д., Бєлялов Т.Е. Сутність та значення стратегічного фінансового планування на підприємстві. навч. посіб. $2018 . \quad$ URL: https://pidru4niki.com/79390/finansi/strategichne_finansove_planuvannya_pidpriyemstvi

3. Базецька Г.І. Фінанси підприємства: планування та управління у виробничій сфері: навч. посіб. Харків: ХНАМГ. 2012. 292 с.

4. Корпоративна звітність - Фармацевтична компанія Дарниця. URL: https://www.darnitsa.ua/reports

5. Кобилецький В. Р., Коефіцієнт рентабельності активів (Коефіцієнт рентабельності пасивів). Онлайн-журнал «Financial Analysis online». URL: https://www.finalon.com/slovnikekonomichnikh-pokaznikiv/337-pokaznik-rentabelnosti-aktiviv-pokaznik-rentabelnosti-pasiviv

6. Кобилецький В. Р., Показник рентабельності реалізованої продукції за чистим прибутком, норма чистого прибутку, маржа чистого прибутку, рентабельність продажів по чистому прибутку, рентабельність виручки. Онлайн-журнал «Financial Analysis online». URL: https://www.finalon.com/slovnik-ekonomichnikh-pokaznikiv/341-pokaznik-rentabelnosti- 
realizovanoji-produktsiji-za-chistim-pributkom-norma-chistogo-pributku-marzha-chistogopributku-rentabelnist-prodazhiv-po-chistomu-pributku

7. Кобилецький В. Р., Коефіцієнт рентабельності власного капіталу. Онлайн-журнал «Financial Analysis online». URL: https://www.finalon.com/slovnik-ekonomichnikhpokaznikiv/338-pokaznik-rentabelnosti-vlasnogo-kapitalu

8. Кобилецький В. Р., Коефіцієнт поточної ліквідності (Коефіцієнт покриття). Онлайнжурнал «Financial Analysis online». URL: https://www.finalon.com/slovnik-ekonomichnikhpokaznikiv/256-pokaznik-potochnoji-likvidnosti-pokaznik-pokrittya

9. Кобилецький В. Р., Коефіцієнт фінансової автономії (Коефіцієнт фінансової незалежності). Онлайн-журнал «Financial Analysis online». URL: https://www.finalon.com/slovnik-ekonomichnikh-pokaznikiv/346-pokaznik-finansovojiavtonomiji-pokaznik-finansovoji-nezalezhnosti

10. Кобилецький В. Р., Коефіцієнт фінансової залежності. Онлайн-журнал «Financial Analysis online». URL: https://www.finalon.com/slovnik-ekonomichnikh-pokaznikiv/347pokaznik-finansovoji-zalezhnosti

11. Кобилецький В. Р., Коефіцієнт мобільності активів. Онлайн-журнал «Financial Analysis online». URL: https://www.finalon.com/slovnik-ekonomichnikh-pokaznikiv/267-koefitsient$\underline{\text { mobilnosti-aktiviv }}$

12. Кобилецький В. Р., Коефіцієнт фінансової стабільності (Коефіцієнт фінансування). Онлайн-журнал «Financial Analysis online». URL: https://www.finalon.com/slovnikekonomichnikh-pokaznikiv/348-pokaznik-finansovoji-stabilnosti-koefitsient-finansuvannya

\section{REFERENCES}

1. Sheludro V.M. (2013) Finansovyiy menedzhment: navch. posibn. Kyiyv: Naukova dumka, 375s.

2. Bilyk M.D., Byelyalov T.E. (2018) Sutnist ta znachennya strategichnogo finansovogo planuvannya na pidpryyemstvi; navch. posibn., URL: https://pidru4niki.com/79390/finansi/strategichne_finansove_planuvannya_pidpriyemstvi

3. Bezecka G.I. (2012) Finansy pidpryyemstva: planuvannya ta upravlinnya u vyrobnychiji sferi: navch. posibn. Harkiv: HNAMG, 292 s.

4. Korporatyvna zvitnist - Farmacevtychna kompaniya Darnycia, URL: https://www.darnitsa.ua/reports

5. Kolybeckiy V.R. Koeficient rentabelnosti aktyviv (Koeficient rentabelnosti pacyviv), Onlaynzhurnal «Financial Analysis online», URL: https://www.finalon.com/slovnik-ekonomichnikhpokaznikiv/337-pokaznik-rentabelnosti-aktiviv-pokaznik-rentabelnosti-pasiviv

6. Kolybeckiy V.R. Pokaznyk rentabelnosti realizovanoyi produkciji za chystym prybutkom, norma chystogo prybutku, rentabelnist prodazhiv po chystomu prybutku, rentabelnist vyruchky, Onlaynzhurnal «Financial Analysis online», URL: https://www.finalon.com/slovnik-ekonomichnikhpokaznikiv/341-pokaznik-rentabelnosti-realizovanoji-produktsiji-za-chistim-pributkom-norma-

chistogo-pributku-marzha-chistogo-pributku-rentabelnist-prodazhiv-po-chistomu-pributku

7. Kolybeckiy V.R. Pokaznik rentabelnosti vlasnogo kapitalu, Onlayn-zhurnal «Financial Analysis online», URL: https://www.finalon.com/slovnik-ekonomichnikh-pokaznikiv/338-pokaznikrentabelnosti-vlasnogo-kapitalu

8. Kolybeckiy V.R. Pokaznik potochnoji likvidnosti (Pokaznik pokrittya), Onlayn-zhurnal «Financial Analysis online», URL: https://www.finalon.com/slovnik-ekonomichnikh-pokaznikiv/256-pokaznikpotochnoji-likvidnosti-pokaznik-pokrittya

9. Kolybeckiy V.R. Pokaznik finansovoji avtonomiji (Pokaznik finansovoji nezalezhnosti), Onlaynzhurnal «Financial Analysis online», URL: https://www.finalon.com/slovnik-ekonomichnikhpokaznikiv/346-pokaznik-finansovoji-avtonomiji-pokaznik-finansovoji-nezalezhnosti 
10. Kolybeckiy V.R. Pokaznik finansovoji zalezhnost, Onlayn-zhurnal «Financial Analysis online», URL: $\quad$ https://www.finalon.com/slovnik-ekonomichnikh-pokaznikiv/347-pokaznik-finansovojizalezhnosti

11. Kolybeckiy V.R. Koefitsient mobilnosti aktiviv, Onlayn-zhurnal «Financial Analysis online», URL: https://www.finalon.com/slovnik-ekonomichnikh-pokaznikiv/267-koefitsient-mobilnosti-aktiviv 12. Kolybeckiy V.R. Pokaznik finansovoji stabilnosti-(Koefitsient finansuvannya), Onlayn-zhurnal «Financial Analysis online», URL: https://www.finalon.com/slovnik-ekonomichnikh-pokaznikiv/348pokaznik-finansovoji-stabilnosti-koefitsient-finansuvannya

Болгов В.Е. к.е.н., доцент кафедры предпринимательства, корпоративной и пространственной экономики, Донецкий национальный университет имени Васыля Стуса Кушнир И.Н., Донецкий национальный университет имени Васыля Стуса, г. Винница МЕХАНИЗМ СТРАТЕГИЧЕСКОГО ФИНАНСОВОГО ПЛАНИРОВАНИЯ НА ПРЕДПРИЯТИИ ЧАО «ФАРМАЦЕВТИЧЕСКАЯ ФИРМА«ДАРНИЦА» МЕТОДОМ КОЭФФИЦИЕНТНОГО АНАЛИЗА

В статье определена роль стратегического финансового планирования как одного из определяющих его методов для предприятия в современных условиях. Авторы исследовали теоретические особенности стратегического финансового планирования: его сущность, принципы и задачи. Очертили основные принципы проведения стратегического финансового планирования на отечественніх предприятий в современніх условиях. Проанализировали динамику финансовых результатов деятельности ЧАО «Фармацевтическая фирма «Дарница». Оценили финансовое состояние ЧАО «Фармацевтическая фирма «Дарница», на базе чего разработали стратегический финансовый план для этого предприятия на основе метода коэффициентного анализа и экономико-математической модели. Проведенные исследования позволили авторам сформировать предложения по улучшению процесса разработки стратегического финансового плана для ЧАО «Фармацевтическая фирма «Дарница»и повышение его эффективности.

Ключевые слова: финансовое стратегическое планирование, показатели деятельности, прогноз, эффективность, анализ

V. Bolhov, Ph.D., Associate Professor Department of Entrepreneurship, Corporate and Spatial Economics, Vasyl` Stus Donetsk National University

I. Kushnir, Vasyl` Stus Donetsk National University

THE MECHANISM OF STRATEGIC FINANCIAL PLANNING AT THE ENTERPRISE OF PJSC «PHARMACEUTICAL FIRM «DARNITSA» BY THE METHOD OF COEFFICIENT ANALYSIS

The article analyzes the role of strategic planning as one of the defining methods of financial planning for the enterprise in modern conditions. The authors explored the theoretical features of strategic financial planning: its essence, principles and objectives. Outlined the basic principles of strategic financial planning for domestic enterprises in modern conditions. Analyzed the dynamics of financial results of PJSC "Pharmaceutical Company «Darnitsa». The financial condition of PJSC Pharmaceutical Company «Darnitsa» was assessed, on the basis of which a strategic financial plan for this enterprise was developed on the basis of the method of coefficient analysis and economic-mathematical model. The conducted research allowed the authors to formulate proposals for improving the process of developing a strategic financial plan for PJSC "Pharmaceutical Company «Darnitsa» and increase its efficiency.

Key words: financial strategic planning, performance indicators, forecast, efficiency, analysis. 